\title{
Detection of zoonotic and livestock-specific assemblages of Giardia duodenalis in free-living wild lizards
}

\author{
Detecção de genótipos de Giardia duodenalis zoonóticos e específicos de ruminantes \\ domésticos em lagartos selvagens
}

\begin{abstract}
Aurora Reboredo-Fernández ${ }^{1}$; Elvira Ares-Mazás ${ }^{1}$; Pedro Galán ${ }^{2}$; Simone Mario Cacciò ${ }^{3}$ Hipólito Gómez-Couso ${ }^{1,4 *}$
${ }^{1}$ Laboratorio de Parasitología, Departamento de Microbiología y Parasitología, Facultad de Farmacia, Universidad de Santiago de Compostela, Campus Vida, Santiago de Compostela, A Coruña, España

${ }^{2}$ Grupo de Investigación en Biología Evolutiva - GIBE, Departamento de Biología, Facultad de Ciencias, Universidad de A Coruña, Campus da Zapateira, A Coruña, España

${ }^{3}$ Malattie Infettive, Parassitarie ed Immunomediate, Istituto Superiore di Sanità, Rome, Italia

${ }^{4}$ Instituto de Investigación y Análisis Alimentarios, Universidad de Santiago de Compostela, Campus Vida, Santiago de Compostela, A Coruña, España
\end{abstract}

Received February 20, 2017

Accepted May 18, 2017

\begin{abstract}
Giardia duodenalis is a zoonotic parasite that infects the gut of a wide range of vertebrates, including numerous wildlife species. However, little is known about this protozoan parasite in reptiles. Fecal samples from 31 wild lizards were collected in Galicia (northwest Spain) and screened for the presence of Giardia by PCR amplification and sequencing of the ITS1-5.8S-ITS2 region in the ribosomal unit. This allowed detection of the parasite in 5 samples $(16.1 \%)$, and enabled identification of $G$. duodenalis assemblage A2 in two samples of Iberian rock lizard (Iberolacerta monticola), $G$. duodenalis assemblage B in other two samples of $I$. monticola, and $G$. duodenalis assemblage $\mathrm{E}$ in one sample of Bocage's wall lizard (Podarcis bocagei). The results obtained after PCR amplification and sequencing of the SSU-rDNA gene confirmed the presence of $G$. duodenalis assemblage A in two samples of $I$. monticola. This is the first report of $G$. duodenalis in free-living lizards, although further studies are needed to distinguish between actual infection and mechanical dissemination of cysts. The detection of zoonotic and livestock-specific assemblages of $G$. duodenalis demonstrates the wide environmental contamination by this parasite, possibly due to human activities.
\end{abstract}

Keywords: Giardia duodenalis, zoonotic assemblages, wild reptiles.

\section{Resumo}

Giardia duodenalis é um parasito zoonótico que infecta o intestino delgado de uma ampla gama de vertebrados, sendo detectado em numerosas espécies selvagens. No entanto, pouco se conhece sobre a presença deste parasito protozoário em répteis. Para estudar a presença de Giardia, foram obtidas amostras fecais provenientes de 31 lagartos e coletadas em diferentes localizaçôes de Galicia (Noroeste da Espanha). Mediante a aplicação da técnica de PCR e posterior sequenciamento da regiâo ITS1-5.8S-ITS2 da unidade ribossômica, detectou-se Giardia em 5 amostras (16,1\%), identificando-se o genótipo A2 de $G$. duodenalis em 2 amostras de lagartos da montanha (Iberolacerta monticola), G. duodenalis genótipo B em outras 2 amostras de I. monticola e G. duodenalis genótipo E em outra amostra de lagarto de Bocage (Podarcis bocagei). Os resultados obtidos, após amplificação e sequenciamento de um fragmento do gene SSU-rDNA, confirmam a presença de $G$. duodenalis genótipo A em 2 amostras de $I$. monticola. Esta é a primeira vez que se descreve $G$. duodenalis em lagartos selvagens, embora sejam necessários outros estudos complementares para confirmar se estes animais sofrem uma infecção real ou se apenas atuam como disseminadores mecânicos da contaminação ambiental. Além disso, a detecção de genótipos zoonóticos e específicos de ruminantes domésticos demonstra a contaminação do ambiente selvagem por $G$. duodenalis, possivelmente devido à atividade humana.

Palavras-chave: Giardia duodenalis, genótipos zoonóticos, répteis selvagens.

*Corresponding author: Hipólito Gómez-Couso. Laboratorio de Parasitología,

Departamento de Microbiología y Parasitología, Facultad de Farmacia,

Universidad de Santiago de Compostela, Campus Vida, 15782, Santiago de

Compostela, A Coruña, España. e-mail: hipolito.gomez@usc.es. 


\section{Introduction}

Traditionally, diseases of wildlife populations have attracted attention mostly if these affect human wellbeing or because of economic implications. Moreover, the emergence of wildlife diseases has been recognized as a threat to domestic animal and human health, as well as a substantial risk to the conservation of global biodiversity (DASZAK et al., 2000). However, during the past decade, an increased number of studies have pointed at the links between human activity and the emergence of wildlife diseases. These studies have assessed the potential role that the anthropogenic environmental alterations and the increasing human encroachment into wild habitats represent as causes of this disease emergence (THOMPSON et al., 2010; BREARLEY et al., 2013). Recently, the investigations of wildlife diseases are recognized as a part of global health and their surveillance has become part of the activities against zoonotic emerging diseases. Therefore, integrated approaches to human and animal health, including their respective social and environmental contexts, are required (ZINSSTAG et al., 2011). Furthermore, the health status of wildlife can be used as an indicator of environmental health (CARIGNAN \& VILLARD, 2002).

Giardia is a genus of flagellated protozoa that infect the gut of different classes of vertebrates. Currently, six species are recognized within this genus: Giardia agilis in amphibians, Giardia ardeae and Giardia psittaci in birds, Giardia muris and Giardia microti in rodents, and $G$. duodenalis in a wide range of mammals. G. duodenalis (syn. Giardia lamblia, Giardia intestinalis) is recognized as a complex of at least eight different assemblages with different host distribution: assemblages $\mathrm{A}$ and $\mathrm{B}$ are found in a wide range of domestic and wild mammals, including humans; assemblages $\mathrm{C}$ and $\mathrm{D}$ are specific for dogs and other canids; assemblage $\mathrm{E}$ is found in livestock; assemblage $\mathrm{F}$ in felids; assemblage $\mathrm{G}$ in rats and assemblage $\mathrm{H}$ in marine mammals (CACCIÒ, 2015).

Species of this genus were first described basing on the presumed host specificity, because of the lack of differentiating morphological features. During the first half of the XX century, over 40 species of Giardia were recognized, two of them in reptiles: Giardia varani from monitor lizard (Varanus niloticus) and Giardia serpentis from Cape viper (Causus rhombeatus) (THOMPSON et al., 1990). In 1952, the increasing number of Giardia species and the uncertainty regarding host specificity led to a taxonomic rationalisation. Thus, most species infecting vertebrates, including those described in reptiles, were named as G. duodenalis (FILICE, 1952). Since then, only one description of a G. varani-like flagellate from a water monitor (Varanus salvator) has been reported in Malaysia (UPTON \& ZIEN, 1997). In the last years, few studies about the presence of Giardia in reptiles, both in wild and in captivity, were carried out, and their results did not show evidence of Giardia species in these hosts (LALLO et al., 2009; RINALDI et al., 2012; RAŚ-NORYŃSKA \& SOKÓL, 2015).

This work reports for the first time the presence of zoonotic and livestock-specific assemblages of $G$. duodenalis in several species of free-living wild lizards from Galicia (northwest Spain), demonstrating the wide environmental contamination by this protozoan parasite, possibly as a result of anthropogenic activities.

\section{Materials and Methods}

\section{Fecal samples}

Thirty-one free-living wild lizards were captured in different locations of the Galician region (northwest Spain) by experienced personnel from the Evolutionary Biology Group, University of A Coruña (UDC). The Spanish protection laws for the endangered species of flora and fauna (Law 9/2001, Law 42/2007 and Decree 88/2007), which are a transposition of the European Directive 86/609/EEC (ESPANA, 2001, 2007a, b; CEU, 1986) were respected. Reptiles were caught by noosing or by hand in the field being identified to species, and released in the same place without injury. Since animals usually defecate as defensive response (GREENE, 1988), fecal samples were collected in situ using plastic bags and stored at $4{ }^{\circ} \mathrm{C}$. The samples belonged to: slow worm (Anguis fragilis, $\mathrm{n}=3$ ), Galani's lizard (Iberolacerta galani, $\mathrm{n}=3$ ), Iberian rock lizard (Iberolacerta monticola, $\mathrm{n}=21$ ), Bocage's wall lizard (Podarcis bocagei, $\mathrm{n}=1$ ), Iberian wall lizard (Podarcis hispanicus, $\mathrm{n}=1$ ), Algerian psammodromus (Psammodromus algirus, $\mathrm{n}=1$ ) and common wall gecko (Tarentola mauritanica, $\mathrm{n}=1$ ). Specimens were from adult and apparently healthy animals.

In the Laboratory of Parasitology, Faculty of Pharmacy, University of Santiago de Compostela, fecal samples were processed using a diphasic concentration method as previously reported (REBOREDO-FERNÁNDEZ et al., 2015). Briefly, samples $(0.21 \pm 0.28 \mathrm{~g})$ were grounded in $10-20 \mathrm{~mL}$ of $0.04 \mathrm{M}$ phosphate buffered saline (PBS), $\mathrm{pH} 7.2$, filtered through a set of two sieves (mesh size 150 and $45 \mu \mathrm{m}$ ), shaken with diethyl ether $(2: 1, \mathrm{~V} / \mathrm{V})$ and centrifuged at $1250 \times \mathrm{g}, 4^{\circ} \mathrm{C}, 15 \mathrm{~min}$. The upper two layers of supernatant were carefully removed and discarded, and the sediment was washed in PBS by centrifugation at $1250 \times \mathrm{g}$, $4{ }^{\circ} \mathrm{C}, 15 \mathrm{~min}$. The resulting pellet was resuspended in $500 \mu \mathrm{l}$ of 0.04 M PBS, pH 7.2.

\section{Molecular characterization of Giardia}

Nucleic acids were extracted from the sediments by using the QIAmp ${ }^{\circledR}$ DNA Stool Mini Kit (QIAGEN ${ }^{\circledR}$, Hilden, Germany), according to the manufacturer's instructions, and DNA was stored at $-20^{\circ} \mathrm{C}$ until use.

Nested-PCR techniques were used to amplify a $\sim 315-b p$ fragment encompassing the ITS1-5.8S-ITS2 region in the ribosomal unit of Giardia (CACCIÒ et al., 2010) and a $\sim 175$-bp fragment of the small subunit ribosomal gene (SSU-rDNA) (READ et al., 2002). DNA of $G$. duodenalis assemblage B obtained from a fecal sample of Patagonian cavy, Dolichotis patagonum, from the zoo of Zagreb (Croatia), donated to the Istituto Superiore di Sanità, Rome (Italy) (isolate code ISSGdA748) and previously characterized at molecular level by Cacciò et al. (2010) and Beck et al. (2011), was used as positive control. Negative controls were included in all experiments. PCR products were subjected to electrophoresis on $2 \%$ agarose/ethidium bromide gels. 
Positive PCR products were purified using the QIAquick ${ }^{\circledR}$ PCR Purification Kit (QIAGEN ${ }^{\circledR}$, Hilden, Germany) and were sequenced in both directions by using the ABI PRISM ${ }^{\circledR}$ BigDye $^{\mathrm{TM}}$ Terminator Cycle Sequencing Kit (Applied Biosystems ${ }^{\circledR}$, Life Technologies ${ }^{\mathrm{TM}}$, Carlsbad, CA, USA), according to the manufacturers' instructions. Sequencing reactions were analyzed using the ABI PRISM ${ }^{\circledR} 3100$ automatic sequencer (Applied Biosystems ${ }^{\circledR}$ ). The sequences were assembled using SeqMan ${ }^{\mathrm{TM}} 7.0$ (DNASTAR ${ }^{\circledR}$, Madison, WI, USA) and compared with other sequences of Giardia spp. deposited in GenBank (National Institute of Health, Bethesda, MD, USA) by using the public web interface of the BLAST 2.2.29 program (http://blast.ncbi.nlm.nih.gov/Blast.cgi, National Center for Biotechnology Information).

\section{Nucleotide sequence accession numbers}

Some sequences obtained in the present study were deposited in the GenBank database under accession numbers KM065501, KM065502, KM065503, KM065506 and KM065507.

\section{Results and Discussion}

This is one of the very few investigations of Giardia in reptiles and the first report of the presence of zoonotic and livestock-specific assemblages of $G$. duodenalis in two species of free-living wild lizards. Thus, among the 31 samples analysed, five samples were positive $(16.1 \%)$, corresponding to Iberian rock lizard (I. monticola) $(4 / 21,19.0 \%)$ and Bocage's wall lizard (P. bocagei) $(1 / 1,100 \%)$ (Table 1$)$. Partial nucleotide sequences of the fragment encompassing the ITS1-5.8S-ITS2 region in the ribosomal unit of Giardia were obtained from all these isolates. Four sequences were 99\% similar to other deposited in GenBank, of which two corresponded to $G$. duodenalis assemblage A2 and the other two to $G$. duodenalis assemblage B (accession numbers GU126432 and GU126440, respectively). The remaining sequence was identical to the livestock-specific $G$. duodenalis assemblage $\mathrm{E}$ $\left(G_{e n B a n k}{ }^{\circledR}\right.$ accession number GU126434). On the other hand, the results of the PCR amplification and sequencing of a fragment of the SSU-rDNA gene show the presence of $G$. duodenalis assemblage $A$ in four of these samples. In two of them, the presence of this assemblage was confirmed, whereas in the two remaining samples, the results were inconsistent in relation with those obtained from the ITS1-5.8S-ITS2 region (see Table 1). These inconsistencies in the results obtained for both molecular markers can be due to the small size of the fragment of the SSU-rDNA gene sequenced (WIELINGA \& THOMPSON, 2007). In any case, the use of this gene allowed the confirmation of the presence of $G$. duodenalis in these hosts.

To the best of our knowledge, this is the first detection of $G$. duodenalis in free-living wild reptiles. Rinaldi et al. (2012) did not identify this parasite in a study carried out in pet reptiles (25 lizards and 125 snakes) surveyed in Italy. Likewise, Giardia was not detected in three wild lizards from Brazil (LALLO et al., 2009). Nevertheless, Giardia cysts were observed in the feces of one chameleon among several pet reptile species analyzed in Poland (76 lizards, 15 turtles and 10 snakes), but the authors did not characterize this isolate at the molecular level (RAŚ-NORYNSKA \& SOKÓL, 2015).

Most Giardia infections naturally occurring in wildlife are caused by zoonotic species, which are considered to have been introduced into wildlife habitats and, once established, maintained by direct contact or environmental routes (THOMPSON, 2013; ABEYWARDENA et al., 2015). The study region (Galicia, northwest Spain) is characterized by an important livestock sector and extensive rural areas, where farmers usually applied slurry as manure in the grasslands. Moreover, the region has a high rainfall and fecal contamination of surface waters by runoff from manure-fertilized fields is common. Thus, assemblage $\mathrm{E}$ is the most frequently $G$. duodenalis genotype detected in surface waters followed by assemblage A (CASTRO-HERMIDA et al., 2015). On the other hand, the lizard species under study feed on flies and other insects that can act as mechanical vectors of this parasite in rural areas, as previously demonstrated by several authors (CONN et al., 2007; ZHAO et al., 2014). Therefore, since hoofed animals are natural hosts for $G$. duodenalis assemblages A, $\mathrm{B}$ and $\mathrm{E}$ (CACCIÒ, 2015) and they were identified in Galician livestock (CASTRO-HERMIDA et al., 2007), the detection of zoonotic and livestock-specific assemblages of $G$. duodenalis in free-living wild lizards indicates the importance that livestock management practices have in the transmission of this parasite.

Finally, the results of the present study increase the number of species in which the presence of Giardia was reported and suggest that this parasite is widely dispersed in wildlife. Although we

Table 1. Presence and molecular characterization of Giardia in free-living wild lizards from Galicia (northwest Spain).

\begin{tabular}{|c|c|c|c|}
\hline Scientific name (common name) & $\begin{array}{l}\text { Analysed samples } \\
\text { (n) }\end{array}$ & $\begin{array}{c}\text { Positive samples } \\
(\%)\end{array}$ & $\begin{array}{c}\text { Molecular characterisation } \\
\text { (ITS1-5.8S-ITS2/SSU- } \\
\text { rDNA) }\end{array}$ \\
\hline Anguis fragilis (slow worm) & 3 & 0 & - \\
\hline Iberolacerta galani (Galani’s lizard) & 3 & 0 & - \\
\hline Iberolacerta monticola (Iberian rock lizard) & 21 & $4(19.0)$ & $\begin{array}{l}\text { G. duodenalis } \mathrm{A} 2 / \mathrm{A} \\
\text { G. duodenalis } \mathrm{A} 2 / \mathrm{A} \\
\text { G. duodenalis } \mathrm{B} / \mathrm{A} \\
\text { G. duodenalis } \mathrm{B} /-\end{array}$ \\
\hline Podarcis bocagei (Bocage's wall lizard) & 1 & $1(100)$ & G. duodenalis E/A \\
\hline Podarcis hispanicus (Iberian wall lizard) & 1 & 0 & - \\
\hline Psammodromus algirus (Algerian psammodromus) & 1 & 0 & - \\
\hline Tarentola mauritanica (common wall gecko) & 1 & 0 & - \\
\hline
\end{tabular}


cannot confirm the existence of real infection in these lizards, the detection of zoonotic and livestock-specific assemblages of $G$. duodenalis supports the increasing evidence that the presence of this protozoon in wildlife is the result of the environmental contamination from anthropogenic activities.

\section{Acknowledgements}

This study was funded by the Spanish Ministry of Education and Science (grant no. CGL-2007-60656) and by the Department of Culture, Education and University of the Autonomous Government of Galicia (grant no. GPC2014-069).

\section{References}

Abeywardena H, Jex AR, Gasser RB. A perspective on Cryptosporidium and Giardia, with an emphasis on bovines and recent epidemiological findings. Adv Parasitol 2015; 88: 243-301. PMid:25911369. http:// dx.doi.org/10.1016/bs.apar.2015.02.001.

Beck R, Sprong H, Bata I, Lucinger S, Pozio E, Cacciò SM. Prevalence and molecular typing of Giardia spp. in captive mammals at the zoo of Zagreb, Croatia. Vet Parasitol 2011; 175(1-2): 40-46. PMid:20970259. http://dx.doi.org/10.1016/j.vetpar.2010.09.026.

Brearley G, Rhodes J, Bradley A, Baxter G, Seabrook L, Lunney D, et al. Wildlife disease prevalence in human-modified landscapes. Biol Rev Camb Philos Soc 2013; 88(2): 427-442. PMid:23279314. http://dx.doi. org/10.1111/brv.12009.

Cacciò SM, Beck R, Almeida A, Bajer A, Pozio E. Identification of Giardia species and Giardia duodenalis assemblages by sequence analysis of the 5.8S rDNA gene and internal transcribed spacers. Parasitology 2010; 137(6): 919-925. PMid:20233487. http://dx.doi.org/10.1017/ S003118200999179X

Cacciò SM. Giardiasis: a zoonotic infection or not? In: Sing A. Zoonoses: infections affecting humans and animals. Heidelberg: Springer; 2015. p. 821-848.

Carignan V, Villard MA. Selecting indicator species to monitor ecological integrity: a review. Environ Monit Assess 2002; 78(1): 45-61. PMid:12197640. http://dx.doi.org/10.1023/A:1016136723584.

Castro-Hermida JA, Almeida A, González-Warleta M, Correia da Costa JM, Rumbo-Lorenzo C, Mezo M. Occurrence of Cryptosporidium parvum and Giardia duodenalis in healthy adult domestic ruminants. Parasitol Res 2007; 101(5): 1443-1448. PMid:17569991. http://dx.doi.org/10.1007/ s00436-007-0624-6.

Castro-Hermida JA, González-Warleta M, Mezo M. Cryptosporidium spp. and Giardia duodenalis as pathogenic contaminants of water in Galicia, Spain: the need for safe drinking water. Int J Hyg Environ Health 2015; 218(1): 132-138. PMid:25270421. http://dx.doi.org/10.1016/j. ijheh.2014.09.001.

Conn DB, Weaver J, Tamang L, Graczyk TK. Synanthropic flies as vectors of Cryptosporidium and Giardia among livestock and wildlife in a multispecies agricultural complex. Vector Borne Zoonotic Dis 2007; 7(4): 643-652. PMid:17979535. http://dx.doi.org/10.1089/vbz.2006.0652.

Council of European Union - CEU. Council Directive of 24 November 1986 on the approximation of laws, regulations and administrative provisions of the Member States regarding the protection of animals used for experimental and other scientific purposes (86/609/EEC) [online]. Brussels: CEU; 1986 [cited 2017 May 18]. Available from: http://www.dantes. info/Tools\&Methods/Othertools/Docs/86.609.EEC.pdf

Daszak P, Cunningham AA, Hyatt AD. Emerging infectious diseases of wildlife-threats to biodiversity and human health. Science 2000; 287(5452): 443-449. PMid:10642539. http://dx.doi.org/10.1126/ science.287.5452.443.

España. Law 9/2001, of 21 august, of nature conservation. Diario Oficial de Galicia [online], Galicia, sept. 2001 [cited 2017 May 18]. Available from: http://www.csd.gob.es/csd/estaticos/inst-dep/armonizacionjuridica/187.pdf

España. Law 42/2007, of 13 december, of natural heritage and biodiversity. Boletín Oficial del Estado, Madrid, dec. 2007a. p. 51275-51327.

España. Decree 88/2007, of 19 april, which regulates the Galician catalogue of threatened species. Diario Oficial de Galicia [online], Galicia, apr. 2007b [cited 2017 May 18]. Available from: http://www.biodiversidade. eu/uploads/documentacion/arquivo/b6b/522f3e8a0d-catalogo-galegoespecies-ameazadas.pdf

Filice FP. Studies on the cytology and life history of a Giardia from the laboratory rat. Berkeley: University of California Press; 1952.

Greene HW. Antipredator mechanisms in reptiles. In: Gans C. Biology of the Reptilia. New York: Alan R Liss; 1988. p. 1-152. vol. 16. Ecology B, Defense and Life History.

Lallo MA, Pereira A, Araújo R, Favorito SE, Bertolla P, Bondan EF. Occurrence of Giardia, Cryptosporidium and microsporidia in wild animals from a deforestation area in the state of São Paulo, Brazil. Cienc Rural 2009; 39(5): 1465-1470. http://dx.doi.org/10.1590/S010384782009005000085 .

Raś-Noryńska M, Sokól R. Internal parasites of reptiles. Ann Parasitol 2015; 61(2): 115-117. PMid:26342508.

Read C, Walters J, Robertson ID, Thompson RCA. Correlation between genotype of Giardia duodenalis and diarrhoea. Int J Parasitol 2002; 32(2): 229-231. PMid:11812501. http://dx.doi.org/10.1016/S00207519(01)00340-X.

Reboredo-Fernández A, Ares-Mazás E, Cacciò SM, Gómez-Couso H. Occurrence of Giardia and Cryptosporidium in wild birds in Galicia (Northwest Spain). Parasitology 2015; 142(7): 917-925. PMid:25669618. http://dx.doi.org/10.1017/S0031182015000049.

Rinaldi L, Capasso M, Mihalca AD, Cirillo R, Cringoli G, Cacciò S. Prevalence and molecular identification of Cryptosporidium isolates from pet lizards and snakes in Italy. Parasite 2012; 19(4): 437-440. PMid:23193530. http://dx.doi.org/10.1051/parasite/2012194437.

Thompson RCA, Lymbery AJ, Meloni B. Genetic variation in Giardia Kunstler, 1882: taxonomic and epidemiological significance. Protozool Abs 1990; 14: 1-28.

Thompson RCA, Lymbery AJ, Smith A. Parasites, emerging disease and wildlife conservation. Int J Parasitol 2010; 40(10): 1163-1170. PMid:20452354. http://dx.doi.org/10.1016/j.ijpara.2010.04.009.

Thompson RCA. Parasite zoonoses and wildlife: one health, spillover and human activity. Int J Parasitol 2013; 43(12-13): 1079-1088. PMid:23892130. http://dx.doi.org/10.1016/j.ijpara.2013.06.007.

Upton SJ, Zien CA. Description of a Giardia varani-like flagellate from a water monitor, Varanus salvator, from Malaysia. J Parasitol 1997; 83(5): 970-971. PMid:9379313. http://dx.doi.org/10.2307/3284303. 
Wielinga CM, Thompson RC. Comparative evaluation of Giardia duodenalis sequence data. Parasitology 2007; 134(12): 1795-1821. PMid:17577426. http://dx.doi.org/10.1017/S0031182007003071.

Zhao Z, Dong H, Wang R, Zhao W, Chen G, Li S, et al. Genotyping and subtyping Cryptosporidium parvum and Giardia duodenalis carried by flies on dairy farms in Henan, China. Parasit Vectors 2014;
7(1): 190-195. PMid:24742088. http://dx.doi.org/10.1186/17563305-7-190.

Zinsstag J, Schelling E, Waltner-Toews D, Tanner M. From "one medicine" to "one health" and systemic approaches to health and well-being. Prev Vet Med 2011; 101(3-4): 148-156. PMid:20832879. http://dx.doi. org/10.1016/j.prevetmed.2010.07.003. 